FULL RESEARCH ARTICLE

\title{
Factors influencing the abundance of wintering western snowy plovers at Crown Memorial State Beach
}

\author{
DAVID L. RIENSCHE*
}

East Bay Regional Park District, 2950 Peralta Oaks Ct, Oakland, CA 94605, USA

*Corresponding Author: driensche@ebparks.org

Survival during the nonbreeding season, when mortality from food shortages and raptor predation is highest, influences shorebird population growth. These selection pressures, as well as anthropogenic influences, can shape wintering shorebird habitat use patterns. The western snowy plover (Charadrius alexandrinus nivosus) is a small shorebird that uses sand-spits, dune-backed beaches, open areas around estuaries for foraging and roosting. The Pacific Coast population of western snowy plovers is listed as a federally threatened species and a California Species of Special Concern. Previous studies suggest humans, dogs and corvids are sources of disturbance to plovers on public beaches. During 2014 to 2019, these disturbance factors were examined at Robert W. Crown Memorial State Beach in Alameda, California. In decreasing order of impact, the beach using public, corvids, and dogs were found to be the major stressors to over wintering plovers. Both the public and corvids respectively, resulted in disturbance and avoidance behaviors by plovers nearly $40 \%$ of the time. In 2015, the District created the Plover Protection Zone (PPZ) by installing symbolic fencing, signage, and establishing a volunteer team to monitor plovers and educate the public. In 2016, the potential prey abundance within the plover protection zone and areas directly north and south were examined using core samples and sticky traps. Statistical analysis showed a significant difference in the amount of macro-invertebrate prey available in the area used by the plovers as compared to other locations. Habitat choice and prey availability are vital to wintering shorebird. During this study, the wintering population of western snowy plovers increased from six to over 54 individuals.

Key words: Charadrius nivosus nivosus, dogs, human recreation, invertebrate prey, management actions, western snowy plover

The western snowy plover (Charadrius nivosus nivosus) is a small light grayish-brown shorebird with black legs and bill, that wears an incomplete dark breast band (Cogswell 1977). The western snowy plover is federally listed as threatened and is a California Spe- 
cies of Special Concern (USFWS 2012; CDFW 2019). Reasons for federal listing include poor productivity, low survival rates (USFWS 1993, 2007), increasing predation (Neuman et al. 2004), human disturbance (Ruhlen et al. 2003; Lafferty et al. 2006), loss of habitat due to development, exotic vegetation, and human recreational activities (Page and Stenzel 1981; USFWS 2007; Muir and Colwell 2010). The Pacific Coast population of the western snowy plover range extends from Damon Point, Washington, USA to Bahia Magdalena, Baja California, Mexico (Page et al. 1995; USFWS 2007). This special status species is dispersed along the coastline with an estimated breeding population of 2,500 individuals (USFWS 2012) and the wintering number of plovers in California varies among sites (Page et al. 1986). Many shorebird populations are declining worldwide (Helmers 1992; Morrison et al. 2006; Delaney et al. 2009; Rosenberg et al. 2019) and the choice of wintering locations plays a vital role in their survival and population growth (Brindock and Colwell 2011). Causes of mortality for wintering shorebirds include food shortages and predation by raptors (Page and Whitacre 1975; Evans and Pienkowski 1984; Cresswell and Quinn 2004). Human activity can mimic raptor predation, causing shorebirds to vacate sites and spend more energy on vigilance and escape, where anthropogenic disturbances are chronic and intense (Pfister et al. 1992; Kirby et al. 1993). Burger (1981) reported that shorebirds show the greatest avoidance to people, and due to this vulnerability, human activity should be restricted around shorebird areas. Lastly, plover populations worldwide occupy habitats favored by humans for recreation (Weston 2019) and studies suggest that human disturbance can limit plover population size and reduces habitat quality.

The piping plover (Charadrius melodus) found along the Atlantic and Gulf coasts of the United States is similar in size to the western snowy plover. During the winter, piping plovers search for sustenance amidst sandflats, ponds, and shorelines. Their foraging efficiency can affect the fat reserves needed for migration and reproduction (Evans 1976; Burger 1994). Studies indicate that piping plover in high human disturbance areas have lower reproductive success due to reduced foraging efficiency and depleted fat reserves (Burger 1986, 1991, 1994; Flemming et al. 1988; Staine and Burger 1994). Likewise, for another closely related plover, food abundance is known to influence habitat selection by the semipalmated plover (Charadrius semipalmatus) (Rose and Nol 2010). Additionally, Brindock and Colwell (2011) concluded that western snowy plovers select habitats with greater food availability and where they can more easily detect predators during the nonbreeding season. They recommend maintaining habitat with attributes that support abundant food and reduce predation risks (i.e., limit obstructive cover) that may be important to individual survival and maintaining the Pacific Coast population of snowy plovers.

Western snowy plovers have wintered on San Francisco Bay since the late 1800s (Page et al. 1986). Along Alameda's South Shore (also known as Robert W. Crown Memorial State Beach) Page et al. (1986) reported a high count of 58 western snowy plovers; however, in recent decades this species has not been recorded with any regularity and presumed absent. During the winter of 2014, a small population of western snowy plovers overwintered along a specific stretch of sand at Robert W. Crown Memorial State Beach. The purpose of this study was three-fold. First, to understand human impacts and other disturbance factors effecting western snowy plovers abundance on a public beach; second, how to restrict public access to the plovers roosting and foraging habitat by establishing a Plover Protection Zone (PPZ; a roped-off area composed of symbolic fencing and signage) adjacent to the beach; and finally, to examine the potential prey availability within the PPZ and in the areas to the north and south. 


\section{METHODS}

\section{Study Area}

The study took place at Robert W. Crown Memorial State Beach (37.76034N, 122.26661W) a 3.2-km sandy beach, located on the east side of San Francisco Bay in the city of Alameda. The site is managed by the East Bay Regional Park District (EBRPD).

\section{Sampling Methods}

From 2014 through 2019, I surveyed the site 610 times for western snowy plovers between the hours of dawn and dusk, amassing a total of 587 observational hours. These monitoring periods ranged from 0.5 to 2 hours (averaging $1 \mathrm{hr}$., due to weather and tide events) and were conducted from a distance greater than $30 \mathrm{~m}$ to avoid disturbance to birds. The plovers typically roosted in one or two small clusters along the same stretch of dry sand near the northern end of Robert W. Crown Memorial State Beach. I used binoculars and a spotting scope to detect plover behavior. Disturbance factors (beach using public, corvids, dogs) were recorded when entering or flying over the PPZ. The time, type of disturbance factor, number, behavior, and direction from/to were recorded, as well as the plovers' predisturbance behavior and post-disturbance reaction (if any). Plover post-disturbance reactions were classified as: no reaction, run and return to previous behavior, fly up and return to previous behavior, fly away and no return, or other.

I performed invertebrate sampling from December 2016 to February 2017 during daylight (0700 - 1430 PST). A 50-m horizontal transect was placed along the wrackline within, north and south of the PPZ. I collected GPS coordinates using a Garmin GPS eTrex 10 along a 50-m transects. Random numbers (between the integers of 0-50) were generated and assigned to three sticky trap sampling locations and five core sampling points. An aluminum Danielson clam gun, marked a 10-cm depth, was used to obtain macro-invertebrate prey availability core sampling along the horizontal transect within the PPZ, and directly north and south. Five vertical transects 5-m in length were distributed along the horizontal transects. I collected in the center, $2.5-\mathrm{m}$ above and below the wrackline. The wrack was moved aside before collecting core sampling. The forty-five core samples were processed and sorted daily. Additionally, I placed sticky traps in horizontal and vertical orientations near the wrackline following methods in Anteau and Sherfy (2010). Setups were left undisturbed for approximately 1 hour (Pearl 2015). The sticky traps were monitored during core sampling to minimize disturbances. After an hour, I placed each sticky trap setups into its own separate plastic bag for further analysis. Macro-invertebrates obtained in both sticky traps and core sampling were brought into the lab where organisms were then identified to their respective taxa under a Nikon SMZ800 microscope. All field work was completed in accordance with the terms and conditions of USFW TE-817400-12 Recovery Permit and CDFW SCP-002298.

\section{Statistical Analyses}

A series of statistical analysis were run for the disturbance factors and for the potential prey availability within the Plover Protection Zone (PPZ) for Western Snowy Plover, with a finding of significance set at $(\alpha=0.10)$ for disturbance factors and $(\alpha=0.05)$ for potential prey availability. The Microsoft Excel® (2016) Chi-Square test was run to compare 
the disturbance factors (beach using public, crows/ravens, and dogs) that may be affecting overwintering Western Snowy Plovers. To compare the change in population of over wintering plovers, following the construction of the PPZ in 2014 through 2019 an $\mathrm{R}^{2}$ value was obtained using IBM SPSS $₫$ Statistics 23 (2018). To test the hypothesis's that there was no significant difference in macro-invertebrate prey abundance (core samples or in sticky traps) within the PPZ and in the areas directly north and south a Chi-Square tests was done using $\left(\mathrm{R}\right.$ Core Team $\left.{ }^{\circledR}, 2019\right)$.

\section{RESULTS}

During the survey effort 6,728 beach using public, I recorded 740 corvids, and 86 dogs within the study area. Human presence was nearly constant, while corvid numbers varied during the study. Western snowy plovers were typically engaged in roosting (80\%) and foraging (20\%) behavior prior to a disturbance event (Table 1). These plovers showed moderately negative responses to the presence of both beach using public and hunting crows/ ravens (Table 1), by displaying "run \& return", "fly \& return" and "fly away" responses cumulatively in $80 \%$ of the observations, respectively. For the beach using public, the plover "run and return" disturbance response was the most recorded during $26 \%$ of the observations (Table 1). Plovers had a statically significant $(\mathrm{P}<0.10)$ negative response to the presence of dogs, at $80 \%$ of the time, with their typical response being the "run and return" (Table 1).

Table 1. Western snowy plover (WSNP) behavior prior to and following disturbance by beach using public, hunting crows and ravens (corvids), and dogs (on or off leash) at Robert W. Crown Memorial State Beach from 2014-2019.

\begin{tabular}{lcccccc}
\hline WSNP Behavior & Roosting & Foraging & No Reaction & Run \& Return & Fly \& Return & Fly Away \\
\hline $\begin{array}{l}\text { Prior to Distur- } \\
\text { bance }\end{array}$ & $80 \%$ & $20 \%$ & $\mathrm{n} / \mathrm{a}$ & $\mathrm{n} / \mathrm{a}$ & $\mathrm{n} / \mathrm{a}$ & $\mathrm{n} / \mathrm{a}$ \\
$\begin{array}{l}\text { Response to } \\
\text { beach using } \\
\text { public }\end{array}$ & $\mathrm{n} / \mathrm{a}$ & $\mathrm{n} / \mathrm{a}$ & $64 \%$ & $26 \%$ & $8 \%$ & $2 \%$ \\
$\begin{array}{l}\text { Response to } \\
\text { hunting corvids }\end{array}$ & $\mathrm{n} / \mathrm{a}$ & $\mathrm{n} / \mathrm{a}$ & $60 \%$ & $22 \%$ & $12 \%$ & $6 \%$ \\
$\begin{array}{l}\text { Response to } \\
\text { dogs }\end{array}$ & $\mathrm{n} / \mathrm{a}$ & $\mathrm{n} / \mathrm{a}$ & $20 \%$ & $60 \%$ & $11 \%$ & $9 \%$ \\
\hline
\end{tabular}

The potential macro-invertebrate prey abundance within the PPZ, and in areas directly north and south resulted in a total of 71 organisms found in the core samples and a total of 533 organism caught in sticky traps. The total number of macro-invertebrate prey items in the core samples within the PPZ was significantly higher $(\mathrm{P}<0.05)$ as compared to the areas directly north and south (Fig. 1). The total number of macro-invertebrate prey items in the sticky traps within the PPZ was significantly higher $(\mathrm{P}<0.05)$ as compared to the areas directly north and south (Fig. 2). Continued analysis of the potential prey items found in the core samples and sticky traps within the PPZ showed that amphipods (Megalorchestia sp.) and flies (Order Diptera) were significantly more abundant $(\mathrm{P}<0.05)$ as compared to the areas directly north and south (Fig. 3) and (Fig. 4) respectively. Lastly, the overwintering population of Western Snowy Plovers showed significantly increased $\left(\mathrm{R}^{2}=0.96\right)$ from 6 to over 54 individuals with the establishment and management of the PPZ at Robert W. Crown Memorial State Beach (Fig. 5). 


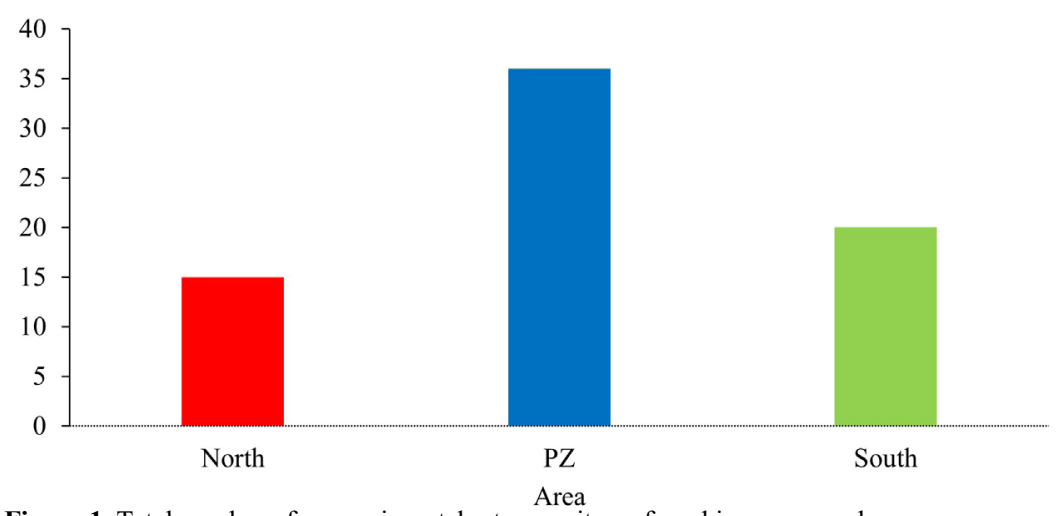

Figure 1. Total number of macro-invertebrate prey items found in core samples.

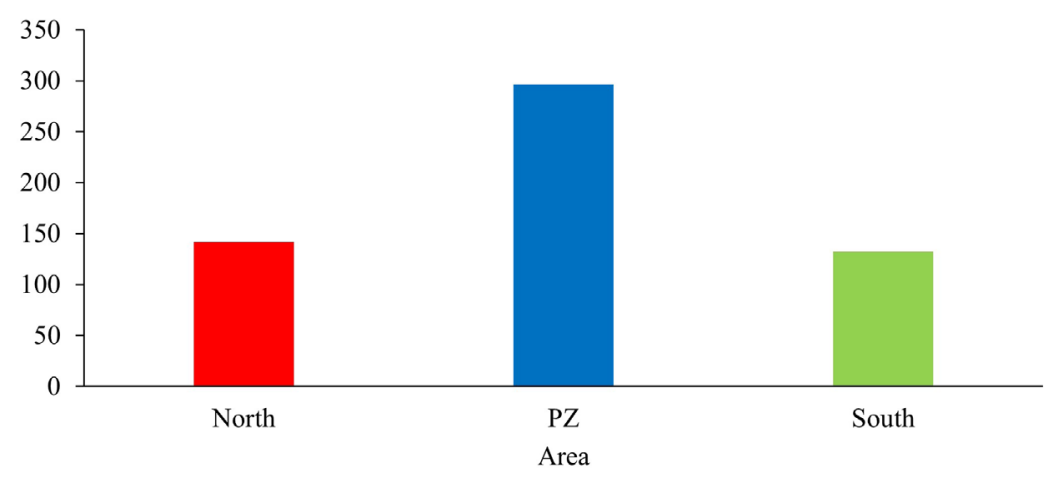

Figure 2. Total number of macro-invertebrate prey items found in Sticky Trap samples.

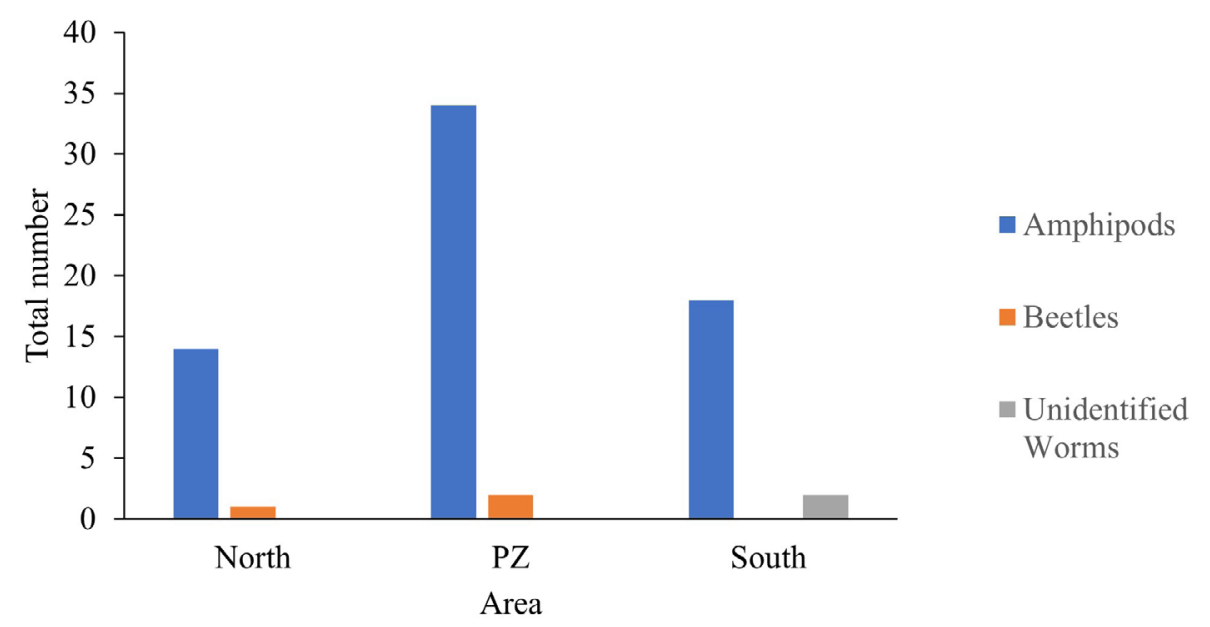

Figure 3. The potential prey items found in the core samples. 


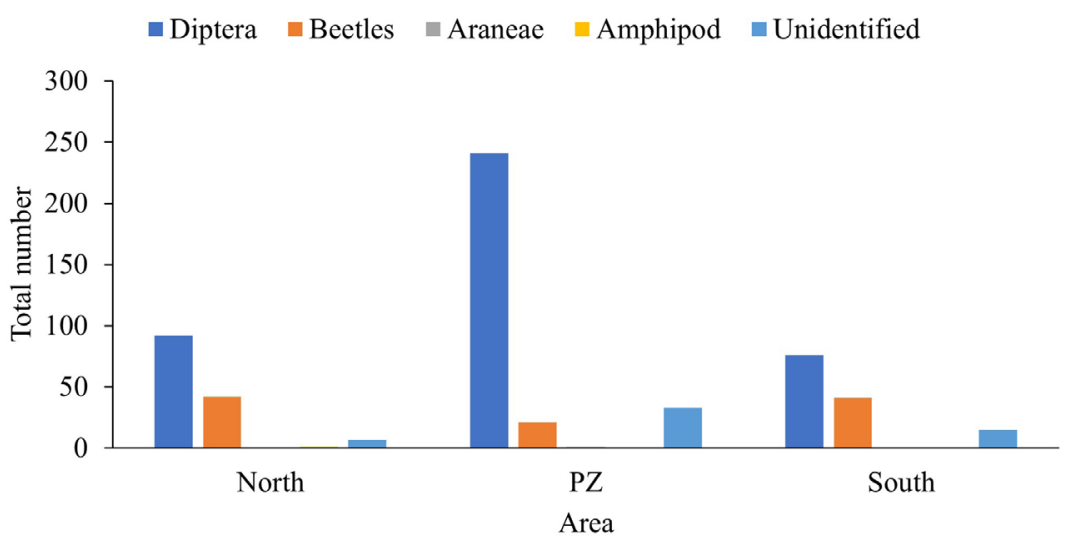

Figure 4. The potential prey items found in the Sticky Trap samples.

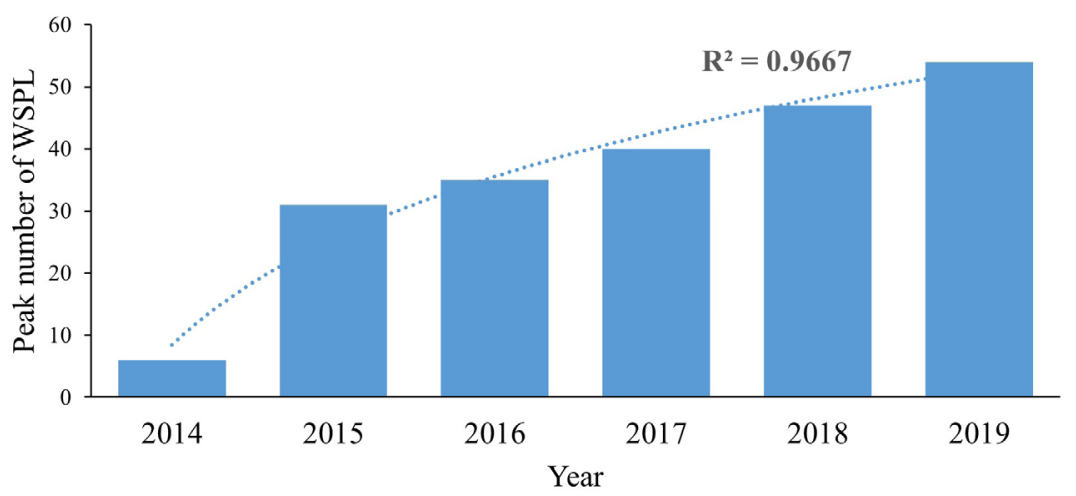

Figure 5. The western snowy plover (WSNP) population trend at Robert Crown Beach State Memorial Park in Alameda, CA, from 2014-2019.

\section{DISCUSSION}

The potential impacts that human disturbance may have on bird populations is a broadly studied issue in conservation biology (Stalmaster and Newman 1978; Belanger and Bedard 1989; Pfister et al.1992; Reijen et al. 1995; Gill 1996). Many studies show that birds avoid areas where humans are present (Stalmaster and Newman 1978; Burger 1981; Tuite et al. 1984; Klein et al. 1995; Reijen et al. 1995). Many shorebirds use sandy beaches and are subject to disturbances by humans and domestic pets that can reduce their resting and foraging opportunities (Brown et al. 2000). Thus, the U.S. Shorebird Conservation Plan requests more information to determine how disturbances affect shorebird populations so that managed areas can be used for educational and outdoor recreational activities that also support conservation recovery goals (Brown et al. 2001). 
Species with little suitable habitat available elsewhere cannot show marked avoidance of disturbance factors even if their fitness costs are high (Gill et al. 2001), whereas species with many alternative sites to move to are likely to avoid disturbances even if the fitness costs are low. For example, Webber et al. (2013) reported that snowy plover site occupancy and colonization in the Florida Panhandle was negatively associated with human disturbance and site extinction was positively associated with these human disturbances. In southern California, where levels of human disturbance are also high, the management of this factor led to an increase in western snowy plover abundance during the nonbreeding season and ultimately the reestablishment of breeding plovers after a 30-year absence (Lafferty et al. 2006). At Robert W. Crown Memorial State Beach, the establishment of symbolic fencing, signage, and volunteers to conduct plover monitoring and public education produced positive results leading to a nearly ten-fold increase in wintering western snowy plovers over a six-year period.

Many wildlife species view dogs as a threat and both unleashed and leashed dogs can have an adverse impact displacing native birds from natural areas (Banks and Bryant 2007). Dogs are known to negatively impact special status species by disrupting their behavior, usage of preferred habitat, affecting their survival rates and reproductive success which contributes to the species population decline (Purdy et al. 1987; Weston et al. 2014). For example, Lafferty (2001) reported that off leash dogs on the beach were a disproportionate source of disturbance and that wintering western snowy plovers were more likely to fly away from dogs than humans. Results obtained at Robert W. Crown Memorial State Beach showed that leashed and unleashed dogs caused negative reactions to western snowy plovers $80 \%$ of the time with the plovers' primary response being "running and returning to their previous behavior" ( $60 \%$ of the time) after the dog was no longer visible. Plovers at this site also showed avoidance behaviors to crows and ravens as corvids are known to predate plover eggs and chicks (Lafferty 2001).

For shorebirds, food availability is an important site selection factor (Brindock and Colwell 2011; Evans 1976). Brindock and Colwell (2011) reported that western snowy plovers, during the non-breeding season chose sites with a higher abundance of brown macroalgae and associated invertebrates such as flies and amphipods. We know from Beeler (2009) that the amount and type of wrack (macroalgae) as well as the abundance of invertebrates can change daily due to storms and other influences. Additionally, plover invertebrate prey items may be found at a range of depths (Nicholls and Baldassarre 1990; Beeler 2009; David Orluck, Humboldt State University, personal communication). Amphipods and flies are both considered major food items for western snowy plovers (Page et al. 1995) and were significantly positively correlated with the presence of plovers along distinct stretches of Robert W. Crown Memorial State Beach. The amount of macro-invertebrate prey (amphipods and flies) available in the PPZ was significantly higher than in the areas directly north and south. It is highly plausible that prey availability is one of the strong factors for plovers selecting this area to overwinter at Robert W. Crown Memorial State Beach. This is consistent with Clark et al. (1993) findings in that plovers select habitat with high food availability and low risk of predation, emphasizing the importance of food on the winter distribution of shorebirds.

Plovers frequently feed on terrestrial insects that cluster around the wrack line where human traffic can disturb foraging plovers (Burger 1994). In this study, it was observed that when foraging plovers were interrupted by human activities, they would stop feeding and move away from the wrack and stand until the disturbance disappeared. Short escape flights are energetically costly to small birds like plovers (Nudds and Bryant 2000). If a plover 
spends significant time avoiding disturbances, it may not be able to dedicate enough time to efficiently find food regardless of invertebrate prey availability (Weston and Elgar 2005) and thus may limit plover survival and population growth (Yasue and Dearden 2006). As Lafferty (2001) inferred few human activities are lethal to roosting plovers. Those impacts can instead be understood by how human disturbances reduce plover foraging and roosting opportunities that can lead to cumulative effects that lower adult survivorship and reproductive potential.

Habitat factors and conditions such as food availability and disturbance are especially critical for shorebird conservation and management when we consider that roughly $50 \%$ of North America's shorebirds are declining and that habitat loss is the leading cause of endangerment of bird species in the United States (Brown et al. 2001; Johnson 2007). This study demonstrates the need to actively manage refuges to reduce disturbance to wintering western snowy plovers. This research showed that plovers are wary of both humans and corvids, with their strongest response to canine owners violating the no-dogs-on-the-beach ordinance. These results complement the findings of Lafferty (2001) in that humans, dogs and crows were the main sources of disturbance to wintering western snowy plovers on public beaches. Likewise, the macro-invertebrate prey analysis supported those of Brindock and Colwell (2011) and Evans (1976) in that food availability is an important influence for habitat selection by plovers. Western snowy plovers overwintering at Robert W. Crown Memorial State Beach habitually used the same stretch of sand during the course of this six-year study. These birds have few alternative roosting sites due to their site fidelity and narrow habitat selection requirements (Lafferty 2001). Lastly, by implementing management actions that decreased human disturbance, such as symbolic fencing (also known as, seasonal fencing; Webber et al. 2013) to dissuade public access at this location led to a nearly ten-fold increase in wintering western snowy plovers. Symbolic fencing is a visual barrier (which may include signage) and consists of removable narrow poles with line running through a hole at the top to make people walk around areas where it may be difficult to see roosting shorebirds.

The anthropogenic change taking place along California's coastline, coupled with rising sea levels and climate change, will intensify the inherent conflicts between humans engaging in certain outdoor recreation and shorebird populations, because both depend on a very narrow strip of sand. In the short term, the most sensible approach may be to concentrate research and protection efforts on threatened species whose populations are declining, and for which human disturbance is implicated as a contributing factor (Gill et al. 2001). Additional research efforts on this topic may consider examining how dune shape, beach debris, the establishment of resource protection areas (PPZ), and access to low and high-energy foraging areas influence overwintering western snowy plover site occupancy and colonization.

\section{LITERATURE CITED}

Anteau, M. J., and M. H. Sherfy. 2010. Diurnal variation in invertebrate catch rates by sticky traps: potential for biased indices of piping plover forage. Wetlands 30:757-762.

Banks, P. B., and J. V. Bryant. 2007. Four-legged friend or foe? Dog walking displaces native birds from natural areas. Biological Letters 3:611-613.

Beeler, H. 2009. Community succession in macroalgal wrack implications for prey resources of breeding western snowy plovers (Charadrius alexandrinus nivosus) on northern California beaches. Thesis, Humboldt State University, Arcata, CA, USA. 
Belanger, L., and J. Bedard.1989. Responses of staging greater snow geese to human disturbance. Journal of Wildlife Management 53:713-719.

Brindock, K. M., and M. A. Colwell. 2011. Habitat selection by western snowy plovers during the nonbreeding season. Journal of Wildlife Management 75:786-793.

Brown, S., C. Hickey, and B. Harrington, editors. 2000. The U.S. Shorebird Conservation Plan. Manomet Center for Conservation Science, Manomet, MA, USA.

Brown, S., C. Hickey, and B. Harrington, editors. 2001. The U.S. Shorebird Conservation Plan. 2nd edition. Manomet Center for Conservation Science, Manomet, MA, USA.

Burger, J. 1981. The effects of human activity on birds at a coastal bay. Biological Conservation 21:231-241.

Burger, J. 1986. The effect of human activity on shorebirds in two coastal bays in the northeastern United States. Environmental Conservation 13:123-130.

Burger, J. 1991. Foraging behavior and the effect of human disturbance on the piping plover (Charadrius melodus). Journal of Coastal Research 7:39-51.

Burger, J. 1994. The effect of human disturbance on foraging behavior and habitat use in piping plover (Charadrius melodus). Estuaries: 17:695-701.

California Department of Fish and Wildlife (CDFW). 2019. List of the state and federal endangered and threatened animals of California. California Department of Fish and Game, Sacramento, CA, USA.

Cogswell, H. L. 1977. Water Birds of California. University Press, Berkeley and Los Angeles. CA, USA.

Cresswell, W., and J. L. Quinn. 2004. Faced with a choice, sparrowhawks more often attack the more vulnerable prey group. Oikos 104:71-76.

Clark, K. E., L. J. Niles, and J. Burger. 1993. Abundance and distribution of migrating shorebirds in Delaware Bay. Condor 95:694-705.

Delaney, S., D. Scott, D. Dodman, and D. Stroud, editors. 2009. An atlas of wader populations in Africa and western Eurasia. Wetland International, Wageningen, Netherlands.

Evans, P. R.1976. Energy balance and optimal foraging strategies in shorebirds: some implications for their distributions and movements in the non-breeding season. Ardea, 64:117-139.

Evans, P. R., and M. W. Pienkowski. 1984. Population dynamics of shorebirds. Pages 83-123 in J. Burger and B. L. Olla, editors. Shorebirds: Breeding Behavior and Populations. Plenum Press, New York, NY, USA.

Flemming, S. P., R. D. Chiasson, P. C. Smith, P. J. Austin-Smith, and R. P. Bancroft. 1988. Piping plover status in Nova Scotia, Canada, related to its reproductive and behavioral response to human disturbance. Journal of Field Ornithology 59:321-330.

Gill, J. A., K. Norris, and W. J. Sutherland. 2001. Why behavioral responses may not reflect the population consequence of human disturbance. Biological Conservation 97:265-268.

Gill, J. A. 1996. Habitat choice in wintering pink-footed geese: quantifying the constraints determining winter site use. Journal of Applied Ecology 33:884-892.

Helmers, D. L. 1992. Shorebird Management Manual. Western Hemisphere Shorebird Reserve Network, Manomet, MA, USA.

Kirby, J. S., C. Clee, and V. Seager. 1993. Impacts and extent of recreational disturbance to 
roosts on the Dee Estuary: some preliminary results. Wader Study Group Bulletin 68:53-58.

Klein, M. L., S. R. Humphrey, and H. F. Percival. 1995. Effects of ecotourism on distribution of waterbirds in a wildlife refuge. Conservation Biology 9:1454-1465.

Johnson, M. D. 2007. Measuring habitat quality: a review. Condor 109:489-504.

Lafferty, K. D. 2001. Disturbance to wintering western snowy plovers. Biological Conservation 101:315-325.

Lafferty, K. D., D. Goodman, and C. P. Sandoval. 2006. Restoration of breeding snowy plovers following protection from disturbance. Biodiversity and Conservation 15:2217-2230.

Morrison, R. I. G., B. J. McCaffery, R. E. Gill, S. K. Skagen, S. L. Jones, G. W. Page, C. L. Gratto-Trevor, and B. A. Andres. 2006. Population estimates of North American shorebirds, 2006. Wader Study Group Bulletin 111:67-85.

Muir, J. J., and M. A. Colwell. 2010. Snowy Plover select open habitats for courtship scrapes and nests. Condor 112:507-510.

Neuman, K. K., G. W. Page, L. E. Stenzel, J. C. Warriner, and J. S. Warriner. 2004. Effect of mammalian predator management on snowy plover breeding success. Waterbirds 27:257-263

Nicholls, J. L., and G. A Baldassarre. 1990. Winter distribution of piping plovers along the Atlantic and Gulf Coasts of the United States. The Wilson Bulletin 102:400-412.

Nudds, R. L., and D. M. Bryant. 2000. The energetic cost of short flights in birds. Journal of Experimental Biology 203:1561-1572.

Page, G. W., and D. F. Whitacre. 1975. Raptor predation on wintering shorebirds. Condor 77:73-83.

Page, G. W., and L. E. Stenzel. 1981. The breeding status of the snowy plover in California. Western Birds 12:1-40.

Page, G. W., F. C. Bidstrup, R. J. Ramer, and L. E. Stenzel. 1986. Distribution of wintering snowy plovers in California and adjacent states. Western Birds 17:145-170.

Page, G. W., J. S. Warriner, J. C. Warriner, and P. W. C. Patton. 1995. Snowy plover (Charadrius alexandrines). Pages 1-24 in A. Poole, and F. Gill, editors. The Birds of North America, No. 154. The Academy of Natural Sciences, Philadelphia, PA, and The American Ornithologists Union, Washington, D.C., USA.

Pearl, B. G. 2015. Factors affecting western snowy plover winter foraging habitat selection in San Francisco Bay ponds. Thesis, San Jose State University, San Jose, CA, USA.

Pfister, C., B. A. Harrington, and M. Lavine. 1992. The impact of human disturbance on shorebirds at a migration staging area. Biological Conservation 60:115-126.

Purdy, K. G., G. R. Goff, D. J. Decker, G. A. Pomerantz, and N. A. Connelly. 1987. A guide to managing human activity on National Wildlife Refuges. Human Dimension Research Unit, Department of Natural Resources, Cornell University, Ithaca, NY, USA.

Reijnen, R., R. Foppen, C. Terbraak, and J. Thissen. 1995. The effects of car traffic on breeding bird population in woodland: reduction of density to proximity of the main road. Journal of Applied Ecology 32:187-202.

Rose, M., and E. Nol. 2010. Foraging behavior of non-breeding semipalmated plovers. Waterbirds 33:59-69. 
Rosenberg, K. V., A. M. Dokter, P. J. Blancher, J. R. Sauer, A. C. Smith, P. A. Smith, J. C. Stanton, A. Panjbi, L. Helft, M. Parr, and P. P. Marra. 2019. Decline of the North American avifauna. Science 366:120-124.

Ruhlen, T. D., S. Abbott, L. E. Stenzel, and G. W. Page. 2003. Evidence that human disturbance reduces snowy plover chick survival. Journal of Field Ornithology 74:300 304.

Staine, K. J., and J. Burger. 1994. Nocturnal foraging behavior of breeding piping plovers (Charadrius melodus) in New Jersey. The Auk 579-587.

Stalmaster, M. V., and J. R. Newman. 1978. Behavioral responses of wintering bald eagle to human activity. Journal of Wildlife Management 42:506-513.

Tuite, C. H., P. R Hanson, and M. Owens. 1984. Some ecological factors affecting winter wildfowl distribution on inland waters in England and Wales, and the influence of water-based recreation. Journal of Applied Ecology 21:41-62.

U.S. Fish and Wildlife Service (USFWS). 1993. Determination of threatened status for the Pacific Coast population of the western snowy plover. Federal Register 58:12864-12874.

U.S. Fish and Wildlife Service (USFWS). 2007. Recovery plan for the Pacific Coast population of the western snowy plover (Charadrius nivosus nivosus). U.S. Fish and Wildlife Service, Sacramento, CA, USA.

U.S. Fish and Wildlife Service (USFWS). 2012. Endangered and Threatened Wildlife and Plants; Revised designation of Critical Habitat for the Pacific Coast population of the western snowy plover; final rule. Federal Register 77:36728-36869.

Webber, A. F., J. A. Heath, and R. A. Fischer. 2013. Human disturbance and stage-specific habitat requirements influence snowy plover site occupancy during the breeding season. Ecology and Evolution 3:853-863.

Weston, M. A., and M. A. Elgar. 2005. Disturbance to brood-rearing hooded plover (Thinornis rubricollis): response and consequences. Bird Conservation International 15:193-209.

Weston, M. A., J. A. Fitzsimons, G. Westcott, K. K. Miller, K. B. Ekanayake, and T. Schneider. 2014. Bark in the park: a review of domestic dogs in parks. Environmental Management 54:373-382.

Weston, M. A. 2019. Human disturbance. Pages 277-308 in M. A. Colwell and S. M. Haig, editors. The Population Ecology and Conservation of Charadrius Plovers. CRC Press, Taylor \& Francis Group, Boca Raton, FL, USA.

Yasue, M., and P. Dearden. 2006. The potential impact of tourism development on habitat availability and productivity of Malaysian plovers (Charadrius peronii). Journal of Applied Ecology 43:97-89.

Submitted 22 November 2020

Accepted 22 January 2021

Associate Editor was V. Monroe 